\title{
PERAN STRES KERJA DAN KEPUASAN KERJA UNTUK MENGURANGI TURNOVER INTENTION
}

\author{
Syarifah Nazenin $\bowtie$, Palupiningdyah $\bowtie$ \\ Fakultas Ekonomi, Universitas Negeri Semarang, Semarang, Indonesia
}

\begin{tabular}{l} 
Info Artikel \\
\hline Sejarah Artikel: \\
Diterima Juni 2014 \\
Disetujui Juli 2014 \\
Dipublikasikan September 2014 \\
\hline Keywords: \\
Job Stress; \\
Job Satisfaction; \\
Turnover Intention
\end{tabular}

\begin{abstract}
Tujuan penelitian ini untuk menguji pengaruh variabel stres kerja dan kepuasan kerja pada turnover intention karyawan tetap bagian produksi. Sampel penelitian ini adalah 86 responden, menggunakan metode Slovin dengan teknik probability sampling dengan jenis proportionate random sampling. Berdasarkan hasil penelitian, menunjukkan bahwa stres kerja berpengaruh positif signifikan pada turnover intention. Kemudian, kepuasan kerja berpengaruh negatif signifikan. Penelitian ini menyimpulkan, bahwa stres kerja berpengaruh positif dan signifikan pada turnover intention karyawan dan kepuasan kerja berpengaruh negatif dan signifikan terhadap turnover intention karyawan. Implikasi manajerial yang bisa dilakukan adalah dengan pengurangan tingkat stres karyawan dan membuat program untuk tujuan menekan turnover intention, seperti kesempatan promosi dan meningkatkan reward karyawan.
\end{abstract}

\section{THE INFLUENCE OF JOB STRESS AND JOB SATISFACTION TOWARD TURNOVER INTENTION}

\begin{abstract}
Abstrak
The purpose of this study conducted to examine the effect of work stress and job satisfaction on turnover intention of employee in production department. The sample was 86 respondent, using Slovin method with proportionate random sampling technique. The result showed that job stress has a positive effect on turnover intention while job satisfaction has a negative effect on turnover intention. This study conclude that job stress has positive and significant impact on employee turnover intention and job satisfaction significantly and negatively related to turnover intention of employees. Therefore, it is recommended to managerial level people to reduce stress levels in employees and to create a program for pressing turnover intention, such as promotional opportunities and improve employee rewards.
\end{abstract}

JEL Classification: M0, M5, M54

\begin{tabular}{lr}
\hline Alamat korespondensi : & ISSN \\
Gedung C6 Lantai 1 FE UNNES & $2086-0668$ (cetak) \\
Kampus Sekaran, Gunungpati, Semarang, 50229 & $2337-5434$ (online) \\
E-mail : Nazenin_syarifah@yahoo.com, upik33@gmail.com &
\end{tabular}


Syarifah Nazenin \& Palupiningdyah / Peran Stres Kerja dan Kepuasan Kerja untuk Mengurangi ...

\section{PENDAHULUAN}

Perubahan kondisi lingkungan organisasi baik internal maupun eksternal secara langsung maupun tidak langsung dapat mempengaruhi tingkat stres kerja karyawan yang dapat menurunkan kepuasan kerja, sehingga dapat menimbulkan niat untuk pindah bagi karyawan (turnover intention) dan pada akhirnya dapat menimbulkan turnover yang sebenarnya (Putra, 2012; Sanjaya, 2012). Menurut Jehanzeb et al. (2013), intensi turnover pada dasarnya adalah sama dengan keinginan berpindahnya karyawan dari satu tempat kerja ke tempat kerja lainnya. Tingginya tingkat turnover karyawan pada perusahaan dapat dilihat dari seberapa besar keinginan berpindah yang dimiliki karyawan suatu organisasi atau perusahaan.

Turnover Intention memiliki dampak negatif bagi organisasi karena menciptakan ketidakstabilan terhadap kondisi tenaga kerja, menurunnya produktifitas karyawan, suasana kerja yang tidak kondusif dan juga berdampak pada meningkatnya biaya sumber daya manusia (Dharma, 2013). Indikator yang digunakan dalam penelitian ini adalah dari Manurung dan Ratnawati (2012), yaitu Intention to quit (niat untuk keluar), Job search (pencarian pekerjaan), dan Thinking of quit (memikirkan untuk keluar).

Banyak faktor yang mempengaruhi turnover intention karyawan, salah satunya stres kerja. Menurut Caesary et al. (2012), menyatakan bahwa stres kerja akan memicu timbulnya kepuasan kerja serta komitmen organisasi sehingga mampu berujung pada fenomena turnover intention sehingga harus diidentifikasi sedemikian rupa supaya organisasi mampu meminimalisasi dampak-dampak buruk akibat turnover intention.

Penyebab stres kerja ada berbagai macam seperti beban kerja yang dirasakan terlalu berat, waktu kerja yang mendesak, kualitas pengawasan kerja yang rendah, iklim kerja yang tidak sehat, otoritas kerja yang tidak memadai yang berhubungan dengan tanggung jawab, konflik kerja, dan perbedaan nilai antara karyawan dengan pemimpin yang frustasi dalam kerja (Mangkunegara, 2009). Indikator yang digunakan untuk variabel stres kerja menurut Caesary et al. (2012) yaitu physical environment stressors (penyebab stres dari lingkungan fisik), individual stressors (penyebab stres dari individu), dan group stressors (penyebab stres dari kelompok).

Menurut Handoko (2001) pada akhirnya stres yang terlalu besar, prestasi kerja akan menurun, karena stres mengganggu pelaksanaan pekerjaan, karyawan kehilangan kemampuan untuk mengendalikannya, menjadi tidak mampu untuk mengambil keputusankeputusan dan perilakunya tidak teratur dan akibat paling ekstrim adalah prestasi kerja menjadi nol karena sakit atau melarikan diri/ pindah kerja (turnover) dan mungkin berhenti.

Stres kerja sangat berpengaruh terhadap turnover intention, apabila stres kerja yang dirasakan karyawan sangat tinggi maka, hal tersebut dapat meningkatkan turnover intention, begitupun sebaliknya apabila tingkat stres kerja karyawan rendah maka hal tersebut dapat mengurangi tingkat turnover intention karyawan. Perusahaan telah berusaha mengurangi stres kerja karyawan dengan membagi pekerjaan ke bagian masing-masing departemen, disana juga sudah ada pembagian kerja dimana karyawan sudah mengetahui pekerjaan apa yang harus dilakukan sesuai dengan tugasnya masingmasing. Sehingga seorang karyawan yang memiliki kejelasan peran atau posisi kerja yang jelas tidak akan merasa stres atau bahkan sampai terjadi turnover. Namun pada kenyatannya disana tingkat turnover tetap saja tinggi. Berdasarkan paparan diatas dapat diusulkan satu hipotesis sebagai berikut:

H1 : Ada pengaruh positif stres kerja terhadap turnover intention karyawan

Selain stres kerja, faktor yang mempengaruhi turnover intention karyawan yaitu kepuasan kerja. Tingkat kepuasan kerja yang tinggi cenderung memiliki kesehatan fisik yang lebih baik, mempelajari tugas yang berhubungan dengan pekerjaan baru dengan lebih cepat, memiliki sedikit kecelakaan kerja, 


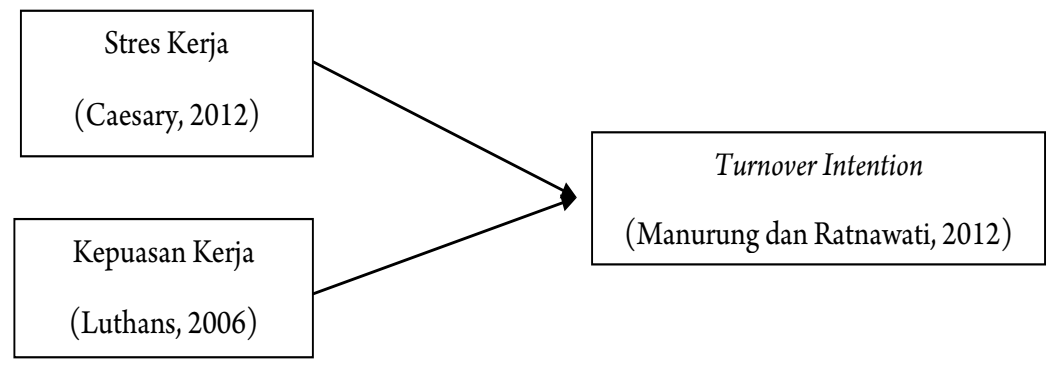

Gambar 1. Model Penelitian

mengajukan sedikit keluhan dan menurunkan tingkat stres (Manurung \& Ratnawati, 2012). Terdapat beberapa faktor penting dalam kepuasan kerja (Robbins \& Judge, 2012) yaitu: (1) pekerjaan yang menantang; (2) pemberian gaji yang adil; (3) kondisi kerja yang mendukung; serta (4) rekan kerja yang mendukung. Indikator yang digunakan untuk variabel kepuasan kerja menurut Manurung dan Ratnawati (2012) yaitu: work it self (pekerjaan itu sendiri), salary (gaji/upah), promotional opportunitie (kesempatan promosi), supervisor (pengawasan), dan work relations (rekan kerja).

Seorang individu akan merasa puas atau tidak puas terhadap pekerjaannya, dan hal tersebutmerupakansesuatuyangbersifatpribadi, yaitu bergantung pada cara ia mempersepsikan adanya kesesuaian atau pertentangan antara keinginan-keinginannya dan hasil keluarannya. Perusahaan telah berusaha meningkatkan kepuasan kerja karyawan dengan memberikan gaji sesuai dengan UMR, pemberian bonus THR, bonus lembur, dan waktu pemberian gaji sesuai dengan aturan yang ditetapkan. Meskipun demikian, pada kenyataanya hal tersebut tidak mampu meningkatkan kepuasan kerja karyawan, sehingga tingkat turnover yang terjadi disana tetap tinggi. Berdasarkan paparan diatas dapat diusulkan satu hipotesis sebagai berikut:

$\mathrm{H} 2$ : Ada pengaruh negatif kepuasan kerja terhadap turnover intention karyawan

Berdasarkan landasan teori diatas maka dapat dibuat model penelitian yang terlihat pada Gambar 1.

\section{METODE}

Populasi dalam penelitian ini adalah karyawan tetap bagian produksi PT. Poliplas Makmur Santosa Ungaran dengan penentuan jumlah sampel menggunakan metode slovin yaitu sebesar 86 karyawan. Teknik pengambilan sampel yang digunakan dalam penelitian ini adalah dengan teknik probability sampling dengan jenis proportionate random sampling. Sumber data dalam penelitian ini diperoleh dari data primer dan data sekunder. Variabel dalam penelitian ini adalah stres kerja (X1), kepuasan kerja (X2), dan turnover intention (Y). Teknik analisis data yang digunakan analisis linier berganda.

\section{HASIL DAN PEMBAHASAN}

Menurut Ghozali (2011) uji validitas digunakan untuk mengukur valid tidaknya suatu instrumen pengukuran yang digunakan, artinya mampu untuk mengungkapkan sesuatu yang akan diukuroleh kuesioner tersebut. Kuesioner dikatakan valid apabila $r$ hitung $>r$ tabel. Hasil uji validitas yang telah dilakukan dengan program SPSS 16.0 dapat dilihat pada Tabel 1.

Hasil uji validitas terhadap variabel stres kerja, kepuasan kerja, dan turnover intention pada Tabel 1 menunjukkan bahwa, seluruh item pernyataan memiliki nilai $r$ pearson correlation $>\mathrm{r}$ tabel maka seluruh variabel penelitian dinyatakan valid.

Hasil uji reliabilitas yang telah dilakukan menggunakan program SPSS 16.0 dapat dilihat pada Tabel 2. Berdasarkan Tabel 2 nilai 
Syarifah Nazenin \& Palupiningdyah / Peran Stres Kerja dan Kepuasan Kerja untuk Mengurangi ...

Tabel 1. Hasil Uji Validitas

\begin{tabular}{|c|c|c|c|}
\hline Item & $\begin{array}{l}\text { rpearson } \\
\text { correlation }\end{array}$ & $\begin{array}{c}r_{\text {tabel }} \\
(\text { Corrected Item }- \text { Total Correlation })\end{array}$ & Kesimpulan \\
\hline $\mathrm{X} 1$ & 0,555 & 0,361 & Valid \\
\hline $\mathrm{X} 2$ & 0,441 & 0,361 & Valid \\
\hline $\mathrm{X} 3$ & 0,691 & 0,361 & Valid \\
\hline $\mathrm{X} 4$ & 0,606 & 0,361 & Valid \\
\hline $\mathrm{X} 5$ & 0,691 & 0,361 & Valid \\
\hline X6 & 0,606 & 0,361 & Valid \\
\hline $\mathrm{X} 7$ & 0,701 & 0,361 & Valid \\
\hline $\mathrm{X} 8$ & 0,441 & 0,361 & Valid \\
\hline X9 & 0,473 & 0,361 & Valid \\
\hline $\mathrm{X} 10$ & 0,701 & 0,361 & Valid \\
\hline $\mathrm{X} 11$ & 0,608 & 0,361 & Valid \\
\hline $\mathrm{X} 12$ & 0,555 & 0,361 & Valid \\
\hline $\mathrm{X} 13$ & 0,545 & 0,361 & Valid \\
\hline $\mathrm{X} 14$ & 0,526 & 0,361 & Valid \\
\hline $\mathrm{X} 15$ & 0,465 & 0,361 & Valid \\
\hline $\mathrm{X} 16$ & 0,728 & 0,361 & Valid \\
\hline $\mathrm{X} 17$ & 0,417 & 0,361 & Valid \\
\hline X18 & 0,614 & 0,361 & Valid \\
\hline X19 & 0,465 & 0,361 & Valid \\
\hline $\mathrm{X} 20$ & 0,728 & 0,361 & Valid \\
\hline $\mathrm{X} 21$ & 0,728 & 0,361 & Valid \\
\hline $\mathrm{X} 22$ & 0,670 & 0,361 & Valid \\
\hline $\mathrm{X} 23$ & 0,754 & 0,361 & Valid \\
\hline $\mathrm{X} 24$ & 0,670 & 0,361 & Valid \\
\hline $\mathrm{X} 25$ & 0,593 & 0,361 & Valid \\
\hline $\mathrm{X} 26$ & 0,618 & 0,361 & Valid \\
\hline $\mathrm{X} 27$ & 0,519 & 0,361 & Valid \\
\hline $\mathrm{X} 28$ & 0,529 & 0,361 & Valid \\
\hline X29 & 0,519 & 0,361 & Valid \\
\hline
\end{tabular}

Sumber: data yang diolah (2014) 
Tabel 1. Lanjutan

\begin{tabular}{cccc}
\hline Item & $\begin{array}{c}\text { r pearson } \\
\text { correlation }\end{array}$ & $\begin{array}{c}\boldsymbol{r}_{\text {tabel }} \\
\text { (Corrected Item }- \text { Total Correlation) }\end{array}$ & Kesimpulan \\
\hline Y1 & 0,719 & 0,361 & Valid \\
Y2 & 0,680 & 0,361 & Valid \\
Y3 & 0,556 & 0,361 & Valid \\
Y4 & 0,707 & 0,361 & Valid \\
Y5 & 0,673 & 0,361 & Valid \\
Y6 & 0,677 & 0,361 & Valid \\
Y7 & 0,782 & 0,361 & Valid \\
Y8 & 0,654 & 0,361 & Valid \\
Y9 & 0,711 & 0,361 & Valid \\
\hline
\end{tabular}

Sumber: data yang diolah (2014)

cronbach's alpha hitung masing-masing variabel $>0,60$ maka seluruh instrumen penelitian dinyatakan reliabel.

Hasil uji normalitas yang telah dilakukan dapat dilihat pada Tabel 3. Dari Tabel 3 diperoleh nilai Asymp sig (2-tailed) $=0,055>$ 0,05 , maka data dikatakan berdistribusi normal.

Hasil uji multikolinieritas yang telah dilakukan dapat dilihat pada Tabel 4. Pada Tabel 4 nilai tolerance stres kerja $0,953>0,1$ dan nilai VIF $1,049<10$ menunjukkan bahwa tidak ada multikolinieritas, nilai tolerance kepuasan kerja 0,953 > 0,1 dan nilai VIF 1,049 < 10 maka tidak terjadi multikolinieritas.

Hasil uji heteroskedastisitas yang telah dilakukan dapat dilihat pada hasil uji glajser pada Tabel 5. Pada hasil output SPSS menunjukan bahwa semua variabel independen mempunyai nilai sig $\geq 0,05$ maka model regresi tidak mengandung adanya heteroskadestisidas.

Hasil uji regresi linear berganda yang telah dilakukan dapat dilihat pada Tabel 6 . Berdasarkan Tabel 6 hasil analisis regresi linier berganda di atas, maka dapat dibentuk persamaan regresi sebagai berikut:

$$
\mathrm{Y}=28,066+0,312 \mathrm{X}_{1}-0,194 \mathrm{X}_{2}
$$

Dari persamaan tersebut, maka hasil persamaan regresi linier berganda tersebut dapat diinterpretasikan, yaitu bahwa: (1) nilai konstanta sebesar 28,066 memiliki arti jika $\beta$ dari variabel stres kerja dan kepuasan kerja sama dengan nol, maka nilai dari variabel turnover intention sebesar 28,066; (2) nilai $\beta$ dari stres kerja sebesar 0,312 artinya apabila ada kenaikan dari nilai stres kerja sebesar satu satuan dengan asumsi nilai variabel kepuasan kerja konstan, maka nilai dari variabel turnover intention $\backslash$ naik sebesar 0,312; serta (3) nilai $\beta$ dari kepuasan kerja menunjukan nilai negatif sebesar 0,194, dapat diartikan bahwa jika kepuasan kerja menurun dan variabel stres kerja konstan, maka nilai dari variabel turnover intention karyawan akan meningkat sebesar 0,194, dan juga sebaliknya jika kepuasan kerja meningkat maka turnover intention karyawan akan menurun Selanjutnya, pada hasil uji $\mathrm{t}$ atau parsial yang telah dilakukan dapat dilihat pada Tabel 7.

Berdasarkan hasil pengujian yang telah dilakukan diperoleh nilai sig hitung pada variabel stres kerja (X1) $0.004<0.05$ maka $\mathrm{H} 1$ yang menyatakan ada pengaruh stres kerja terhadap turnover intention karyawan didukung. Hal tersebut menunjukkan bahwa, turnover 
Syarifah Nazenin \& Palupiningdyah / Peran Stres Kerja dan Kepuasan Kerja untuk Mengurangi ...

Tabel 2. Hasil Uji Reliabilitas

\begin{tabular}{clccc}
\hline No & \multicolumn{1}{c}{ Variabel } & $\begin{array}{c}\text { Cronbach } \\
\text { Alpha }\end{array}$ & $\begin{array}{c}\text { Cronbach Alpha } \\
\text { yang disyaratkan }\end{array}$ & Kesimpulan \\
\hline 1 & Stres Kerja & 0.743 & 0.60 & Reliabel \\
2 & Kepuasan Kerja & 0.749 & 0.60 & Reliabel \\
3 & Turnover Intention & 0.768 & 0.60 & Reliabel \\
\hline
\end{tabular}

Sumber: data yang diolah (2014)

Tabel 3. Hasil Uji Normalitas

One-Sample Kolmogorov-Smirnov Test

Unstandardized Residual

\begin{tabular}{llr}
\hline N & & 83 \\
Normal Parameters & Mean & .0000000 \\
& Std. Deviation & 4.89939372 \\
Most Extreme Differences & Absolute & .147 \\
& Positive & .112 \\
& Negative & -.147 \\
Kolmogorov-Smirnov Z & & 1.341 \\
Asymp.Sig. (2-tailed) & & .055 \\
\hline
\end{tabular}

a. Test distribution is Normal.

Sumber: data yang diolah (2014)

Tabel 4. Hasil Uji Multikolinieritas

Coefficients $^{a}$

\begin{tabular}{|c|c|c|c|c|c|c|c|}
\hline \multirow[t]{2}{*}{ Model } & \multicolumn{2}{|c|}{ Unstandardized Coefficients } & $\begin{array}{c}\text { Standardized } \\
\text { Coefficients }\end{array}$ & \multirow[t]{2}{*}{$\mathrm{t}$} & \multirow[t]{2}{*}{ Sig. } & \multicolumn{2}{|c|}{$\begin{array}{l}\text { Collinearity } \\
\text { Statistics }\end{array}$} \\
\hline & $\mathrm{B}$ & Std. Error & Beta & & & Tolerance & VIF \\
\hline 1 (Constant) & 28.066 & 6.563 & & 4.276 & .000 & & \\
\hline $\mathrm{X} 1$ & .312 & .105 & .305 & 2.967 & .004 & .953 & 1.049 \\
\hline $\mathrm{X} 2$ & -.194 & .077 & -.260 & -2.526 & .013 & .953 & 1.049 \\
\hline
\end{tabular}

Sumber: data yang diolah (2014)

Tabel 5. Hasil Uji Glajser

Coefficients $^{a}$

\begin{tabular}{|c|c|c|c|c|c|}
\hline \multirow[t]{2}{*}{ Model } & \multicolumn{2}{|c|}{ Unstandardized Coefficients } & $\begin{array}{l}\text { Standardized } \\
\text { Coefficients }\end{array}$ & \multirow[t]{2}{*}{$\mathrm{t}$} & \multirow[t]{2}{*}{ Sig. } \\
\hline & B & Std. Error & Beta & & \\
\hline (Constant) & -1.664 & 3.922 & & -.424 & .672 \\
\hline $\mathrm{X} 1$ & .073 & .063 & .131 & 1.162 & .249 \\
\hline $\mathrm{X} 2$ & .048 & .046 & .118 & 1.045 & .299 \\
\hline
\end{tabular}

a. Dependent Variable: ABSRES

Sumber: data yang diolah (2014) 
Tabel 6. Hasil Uji Regresi Linear Berganda

Coefficients $^{a}$

\begin{tabular}{|c|c|c|c|c|c|c|}
\hline \multirow[b]{2}{*}{ Model } & \multicolumn{2}{|c|}{$\begin{array}{l}\text { Unstandardized } \\
\text { Coefficients }\end{array}$} & \multirow{2}{*}{$\begin{array}{c}\text { Standardized } \\
\text { Coefficients } \\
\text { Beta }\end{array}$} & \multirow[b]{2}{*}{$\mathrm{T}$} & \multirow[b]{2}{*}{ Sig. } & $\begin{array}{c}\text { Collinearity } \\
\text { Statistics }\end{array}$ \\
\hline & $\mathrm{B}$ & Std. Error & & & & Tolerance VIF \\
\hline 1 (Constant) & 28.066 & 6.563 & & 4.276 & .000 & \\
\hline X1 & .312 & .105 & .305 & $2.9 c$ & .004 & .9531 .049 \\
\hline $\mathrm{X} 2$ & -.194 & .077 & -.260 & -2.526 & .013 & $.953 \quad 1.049$ \\
\hline
\end{tabular}

a. Dependent Variable: $Y$

Sumber: data yang diolah (2014)

Tabel 7.Hasil Uji t atau Parsial

Coefficients $^{a}$

\begin{tabular}{lrrrrr}
\hline \multirow{2}{*}{ Model } & \multicolumn{2}{c}{ Unstandardized Coefficients } & $\begin{array}{c}\text { Standardized } \\
\text { Coefficients }\end{array}$ & \multicolumn{1}{c}{$\mathrm{T}$} & \multirow{2}{*}{ Sig. } \\
\cline { 2 - 4 } & \multicolumn{1}{c}{$\mathrm{B}$} & Std. Error & \multicolumn{1}{c}{ Beta } & & \\
\hline 1 (Constant) & 28.066 & 6.563 & & 4.276 & .000 \\
X1 & .312 & .105 & .305 & 2.967 & .004 \\
X2 & -.194 & .077 & -.260 & -2.526 & .013 \\
\hline
\end{tabular}

a. Dependent Variable: Y

Sumber: data yang diolah (2014)

intention dipengaruhi oleh stres kerja dengan indikator penyebab stres dari lingkungan fisik, penyebab stres dari individu, penyebab stres kerja dari kelompok, dan penyebab stres dari organisasi. Dari empat indikator tersebut yang paling berpengaruh adalah indikator penyebab stres kerja dari lingkungan fisik. Hal tersebut terjadi karena pada ruangan bagian produksi memiliki lingkungan fisik yang kurang baik, seperti suhu ruangan yang panas, suara yang bising pada ruang kerja, dan pengaturan tempat kerja yang tidak tertata. Hal tersebut dapat membuat karyawan merasa tidak nyaman dan terganggu dalam bekerja, sehingga dapat menyebabkan karyawan merasa stres dan mampu menjadikan turnover. Hal tersebut mendukung hasil penelitian dari Caesary (2012), yang menjelaskan bahwa stres kerja berpengaruh positif dan signifikan terhadap turnover intention.

Berdasarkan hasil pengujian yang telah dilakukan diperoleh nilai sighitung pada variabel kepuasan kerja $(\mathrm{X} 2) 0.013<0.05$, maka $\mathrm{H} 2$ yang menyatakan ada pengaruh kepuasan kerja terhadap turnover intention karyawan didukung. Hal tersebut menunjukkan bahwa turnover intention juga dipengaruhi oleh kepuasan kerja dengan indikator pekerjaan itu sendiri, gaji/ upah, kesempatan promosi, pengawasan, dan rekan kerja. Dari lima indikator tersebut yang paling berpengaruh adalah indikator kesempatan promosi. Hal tersebut terjadi karena para karyawan merasa bahwa mereka belum merasa puas pada kesempatan promosi yang diberikan oleh perusahaan terhadap karyawan.

Karyawan mempersepsikan bahwa perusahaan belum memberikan kesempatan promosi yang sesuai dengan hasil kerja merkeka. Kesempatan promosi yang diberikan perusahaan bisa promosi jabatan maupun promosi kenaikan gaji, karena ketidakpuasan inilah yang dapat menjadi penyebab karyawan ingin keluar dari pekerjaannya. Hal tersebut mendukung hasil penelitian dari Manurung dan Ratnawati (2012), yang menjelaskan bahwa kepuasan kerja berpengaruh negatif dan signifikan terhadap turnover intention. 
Syarifah Nazenin \& Palupiningdyah / Peran Stres Kerja dan Kepuasan Kerja untuk Mengurangi ...

\section{SIMPULAN DAN SARAN}

Simpulan dari penelitian ini terbukti bahwa stres kerja berpengaruh positif dan signifikan terhadap turnover intention karyawan tetap bagian produksi. Hal ini berarti semakin tinggi stres kerja karyawan maka akan meningkatkan turnover intention karyawan, sebaliknya semakin rendah stres kerja karyawan maka akan menurunkan turnover intention karyawan. Kepuasan kerja berpengaruh negatif dan signifikan terhadap turnover intention karyawan tetap bagian produksi. Hal ini berarti semakin rendah kepuasan kerja karyawan maka akan meningkatkan turnover intention karyawan, sebaliknya semakin tinggi kepuasan kerja karyawan maka akan menurunkan turnover intention karyawan.

Implikasi manajerial dari hasil penelitian hendaknya perusahaan membuat kebijakan untuk mengurangi stres karyawan dengan cara menambah pendingin ruangan untuk mengurangi suhu panas, memberikan penyuluhan tentang perlunya kedisiplinan dalam penggunaan alat pelindung telinga untuk mengurangi bising, dan merapikan tempat kerja agar tidak mengganggu karyawan dalam bekerja. Dan meningkatkan kepuasan kerja, dengan cara memberikan kesempatan promosi pada karyawan, baik promosi jabatan atau promosi kenaikan gaji dan penambahan fasilitas-fasilitas penunjang pekerjaan pegawai yang belum ada sebelumnya maupun yang sudah ada tetapi masih dirasa sangat kurang.

Implikasi teoritis bagi peneliti selanjutnya yang tertarik melakukan penelitian sejenis diharapkan untuk menambahkan variabel lain seperti komitmen organisasi, budaya organisasi, kepemimpinan dan lingkungan kerja yang tentu saja disesuaikan dengan objek penelitian.

\section{DAFTAR PUSTAKA}

Caesary, A. G. 2012. Analisis faktor-faktor yang mempengaruhi Turnover Intention pada Agent Outbound call PT. Infomedia Nusantara menggunakan Metode Structural Equation Modelling. Surabaya: Institut Teknologi Sepuluh Nopember.

Dharma, C. 2013.Hubungan Antara Turnover Intention Dengan Komitmen Organisasional di PT. X Medan. Jurnal Ekonomi dan Bisnis Jurusan Administrasi Niaga Politeknik Negeri Medan. 1 (2): 1-9.

Ghozali, I. 2011. Aplikasi Analisis Multivariate dengan program IBM SPSS 19. Semarang: Badan Penerbit Universitas Diponegoro.

Handoko, T. H. 2001. Manajemen Personalia dan Manajemen Sumber Daya Manusia. Yogyakarta: Universitas Gajah Mada.

Mangkunegara, P. 2009. Manajemen Sumber Daya Manusia Perusahaan. Bandung: Rosda.

Manurung, M. T \& Ratnawati, I. 2012. Analisis Pengaruh Stres Kerja dan Kepuasan Kerja terhadap Turnover Intention Karyawan: Studipada STIKES Widya Husada Semarang. Diponegoro Journal of Management. 1 (2): $145-157$

Nasution, W. A. 2009. "Pengaruh Kepuasan Kerja Karyawan terhadap Intensi Turnover pada Call Center Telkomsel di Medan”. Jurnal Mandiri. 4 (1): 1-11.

Putra, B. R. 2012. Pengaruh Job Stressor terhadap Turnover Intention dengan Kepuasan Kerja sebagai Variabel Pemediasi. Jurnal Studi Manajemen. 1 (2): 72-81.

Sanjaya, F. 2012. Peran Moderasi Kecerdasan Emosi pada Stres Kerja. Jurnal Dinamika Manajemen. 3 (2); 155-163.

Umam, K. 2010. Perilaku Organisasi. Bandung: Pustaka Setia.

Robbins, S. P \& Judge, T. A. 2008. Perilaku Organisasi, Edisi 12. Semarang: Salemba Empat. 